\title{
Performance of fungicides on the control of fusarium head blight (Triticum aestivum L.) and deoxynivalenol contamination in wheat grains
}

\author{
Éverson Bilibio Bonfada ${ }^{1} \oplus$, Daniela Honnef ${ }^{2} \odot$, Maria Tereza Friedrich ${ }^{3} \bullet$, Walter Boller ${ }^{4} \oplus$, Carolina Cardoso Deuner ${ }^{4}$
}

\begin{abstract}
${ }^{1}$ Master's student, Graduate Program in Agronomy (PPGAgro), University of Passo Fundo, Rodovia BR-285, km 292.7, Campus I, Bairro São José, Passo Fundo/RS, Brazil, CEP 99052-900. ${ }^{2}$ Master's student, Graduate Program in Food Science and Technology (PPGCTA), University of Passo Fundo, Rodovia BR-285, km 292.7, Campus I, Bairro São José, Passo Fundo/RS, Brazil, CEP 99052-900. ํㅜrofessor, Graduate Program in Food Science and Technology (PPGCTA), University of Passo Fundo, Rodovia BR-285, km 292.7, Campus I, Bairro São José, Passo Fundo/ RS, Brazil, CEP 99052-900. ${ }^{4}$ Professor, Graduate Program in Agronomy (PPGAgro), University of Passo Fundo, Rodovia BR-285, km 292.7, Campus I, Bairro São José, Passo Fundo/RS, Brazil, CEP 99052-900.

Corresponding author: Éverson Bilibio Bonfada(everson_bonfada@hotmail.com)
\end{abstract}

Data de chegada: 22/02/2018. Aceito para publicação em: 05/02/2019.

$10.1590 / 0100-5405 / 191941$

\begin{abstract}
Bonfada, E. B.; Honnef, D.; Friedrich, M. T.; Boller, W.; Deuner, C. C.; Performance of fungicides on the control of fusarium head blight (Triticum aestivum L.) and deoxynivalenol contamination in wheat grains. Summa Phytopathologica, v.45, n.4, p.374-380, 2019.

Fusarium head blight (FHB) is considered a disease of difficult control in a scenery of obstacles for its chemical control and due to the aggressiveness of its pathogen in producing toxins. Thus, the objective of this study was to verify if fungicides of different chemical groups, alone or in combination, are effective in controlling fusarium head blight and reducing deoxynivalenol (DON) contamination in wheat grains. In addition, pyraclostrobin alone was evaluated for possible changes on fusarium head blight intensity and DON accumulation reflecting on the yield. The experiments were conducted in the field, in a randomized block design, containing 11 treatments and four replicates, using the cultivar TBIO Toruk. The treatments were

composed of the fungicides triazole, strobilurin and benzimidazole alone, besides the commercial mixture of triazole + strobilurin. Two fungicide applications were performed during the crop flowering. Fusarium head blight intensity, control efficacy, DON contamination and grain yield were evaluated. Data were subjected to analysis of variance (F-Test at 5\%) and means were compared according to Scott-Knott test, at 5\%. Carbendazim alone presented greater control efficacy in the two studied years $(67 \%$ and $75 \%$, respectively), differing from metconazole and pyraclostrobin. Pyraclostrobin at different doses and application stages changed fusarium head blight intensity, DON contamination and wheat grain yield.
\end{abstract}

Keywords: Triticum aestivum, chemical control, fusarium, toxins.

\section{RESUMO}

Bonfada, E. B.; Honnef, D.; Friedrich, M. T.; Boller, W.; Deuner, C. C. Desempenho de fungicidas no controle de giberela (Triticum aestivum L.) e contaminação por deoxynivalenol em grãos de trigo. Summa Phytopathologica, v.45, n.4, p.374-380, 2019.

A giberela é considerada uma doença de difícil controle, num cenário de dificuldades no seu controle químico e pela agressividade do patógeno em produzir toxinas. Diante disso, o objetivo do estudo foi verificar se fungicidas de distintos grupos químicos, isolados ou em mistura são eficazes no controle de giberela e na redução da contaminação de desoxinivalenol (DON) em grãos de trigo. Além disso, avaliar se a piraclostrobina isolada, altera a intensidade de giberela, o acúmulo de DON com reflexo no rendimento. Os experimentos foram conduzidos no campo, com delineamento de blocos ao acaso, contendo 11 tratamentos e quatro repetições, utilizando a cultivar TBIO Toruk. Os tratamentos foram compostos por fungicidas triazol, estrobilurina e benzimidazol isoladamente, além da mistura comercial de triazol + estrobilurina. Realizou-se duas aplicações dos fungicidas durante o florescimento da cultura. Avaliou-se a intensidade da giberela, eficácia do controle, contaminação de DON e o rendimento de grãos. Os dados foram submetidos à análise da variância (F-Teste a 5\%) e a comparação de médias pelo teste de Scott-Knott, a 5\%. O carbendazim isoladamente, foi o mais eficiente no controle nos dois anos estudados (67 e $75 \%$, respectivamente), distinguindo-se do metconazol e da piraclostrobina. A utilização de piraclostrobina em diferentes doses e estádios de aplicação alteraram a intensidade da giberela, a contaminação de DON e o rendimento de grãos do trigo.

Palavras-chave: Triticum aestivum, controle químico, fusariose, toxinas.

Fusarium head blight, caused by the fungus Fusarium graminearum Schwabe, teleomorph Gibberella zeae (Schwein) Petch, occurs in most winter cereals, leading to severe epidemics; thus, it is considered one of the biggest causes of loss in wheat crops in the South region of Brazil (14). Besides being disseminated around the world, this pathogen is known for its destructive capacity, affecting the productivity of cereals and the quality of grains (10). Damages are, in great part, associated with reduced grain production and seed quality, which are also aggravated by the contamination of grains with mycotoxins, particularly deoxynivalenol (DON) (4).

In terms of food security, deoxynivalenol is highly toxic, constituting a serious and harmful threat to the health if grains contaminated with Fusarium strains are used in human and animal food $(23,25)$. Among control strategies for fusarium head blight, the use of fungicides has been recommended worldwide, while cultivars showing high genetic resistance degrees are not available to wheat 
producers. Some fungicides may not be effective in controlling fusarium head blight in severe epidemics; however, in years of weak epidemics, the use of fungicide may be sufficient to reduce DON contamination (20). Lower fungicide doses tend to increase mycotoxin production by the fungus (9). Nevertheless, there are several fungicides studied for their effects on disease control and DON contamination. Some fungicides, representatives of the strobilurin chemical group (Quinone Outside Inhibitors), like azoxystrobin and trifloxystrobin, can result in increased DON accumulation (12), especially due to application of sub-doses of azoxystrobin, significantly reducing the disease and increasing DON levels (21). However, studies about pyraclostrobin on DON contamination in wheat grains were not found in the literature.

Triazoles and strobilurins are among the most commonly used fungicides for F. graminearum control (27), whereas in vitro studies have found no influence of azoxystrobin on conidial germination, mycelial growth and fungal biomass (7). The same studies have reported that the effectiveness of fungicides of the triazole chemical group against Fusarium species is certain, while the effectiveness of strobilurins is doubtful and controversial. Besides, benzimidazolic fungicides, especially carbendazim, have been used to control fusarium head blight for several years, especially in China, where resistance to this chemical group has already been reported. Hypothetically, resistance can lead to increased efficiency of the fungus in producing mycotoxins, showing consistency for this fungicide in relation to the disease incidence in spikelets and production of mycotoxins (29).

Reports on the effect of fungicides on fusarium head blight control are limited, showing results that vary according to several environmental factors (27) such as the application technology (19). Therefore, the objective of this study was to verify whether distinct fungicide chemical groups, used alone or in combination, are effective in controlling fusarium head blight and reducing contamination by DON toxin in wheat. In addition, this paper aimed to evaluate if the fungicide pyraclostrobin, of the strobilurin chemical group, changes the intensity of fusarium head blight in cobs, DON contamination and yield of wheat when used alone.

\section{MATERIAL AND METHODS}

\section{Experimental site and establishment of the crop}

The used wheat cultivar was $\mathrm{TBIO}^{\circledR}$ Toruk, classified as wheat bread/breeder, of average cycle. The experiment was repeated in two consecutive crop years (first year: 2016, and second year: 2017) in the experimental field of University of Passo Fundo/RS, the geographical coordinates of which are $28^{\circ} 13^{\prime} 29.9^{\prime \prime} \mathrm{S}, 52^{\circ} 23^{\prime} 06.1^{\prime \prime} \mathrm{W}$ and altitude of 703 meters.

The climate is classified as Cfa (humid subtropical), according to Köppen classification. The meteorological data of pluvial precipitation $(\mathrm{mm})$, relative humidity $(\%)$ and temperature $\left({ }^{\circ} \mathrm{C}\right)$ were obtained from the automatic meteorological station of INMET-National Institute of Meteorology, located in Passo Fundo, during the experiments, from 01/07/2016 to $21 / 11 / 2016$ (Figure 1) and $26 / 06 / 2017$ to $13 / 11 / 2017$ (Figure 2).

Treatments and designFusarium head blight control program was defined with two fungicide applications during wheat flowering. The first application was performed when anthesis was approximately $10 \%$ (before wetting) and the second application was performed after seven days, corresponding to stages 60 and 65, respectively, according to the phenology scale of Zadoks et al. (28). The treatment "1-Test (without fungicide)" did not receive fungicide application throughout the crop cycle, representing an absolute control; the treatment "2-Test (control of foliar diseases)", for the assessment of foliar disease control in pre-anthesis of wheat, received two applications of the fungicides trifloxystrobin + prothioconazole $(87.5+75.0 \mathrm{~g}$ a.i. $)$. In the first year, applications were carried out in stages 32 and 40 (28), respectively. In the second year, only one application was performed in stage 35 , due to the lower occurrence of foliar diseases at the beginning of the crop cycle; all the other treatments ( 2 to 11 ) received the same applications for assessment of foliar disease control (Table 1).

Unifactorial experimental design was adopted with 11 treatments (Table 2) in randomized blocks and four replicates. The control protocol was composed of different fungicides and resulting doses (Table 1).

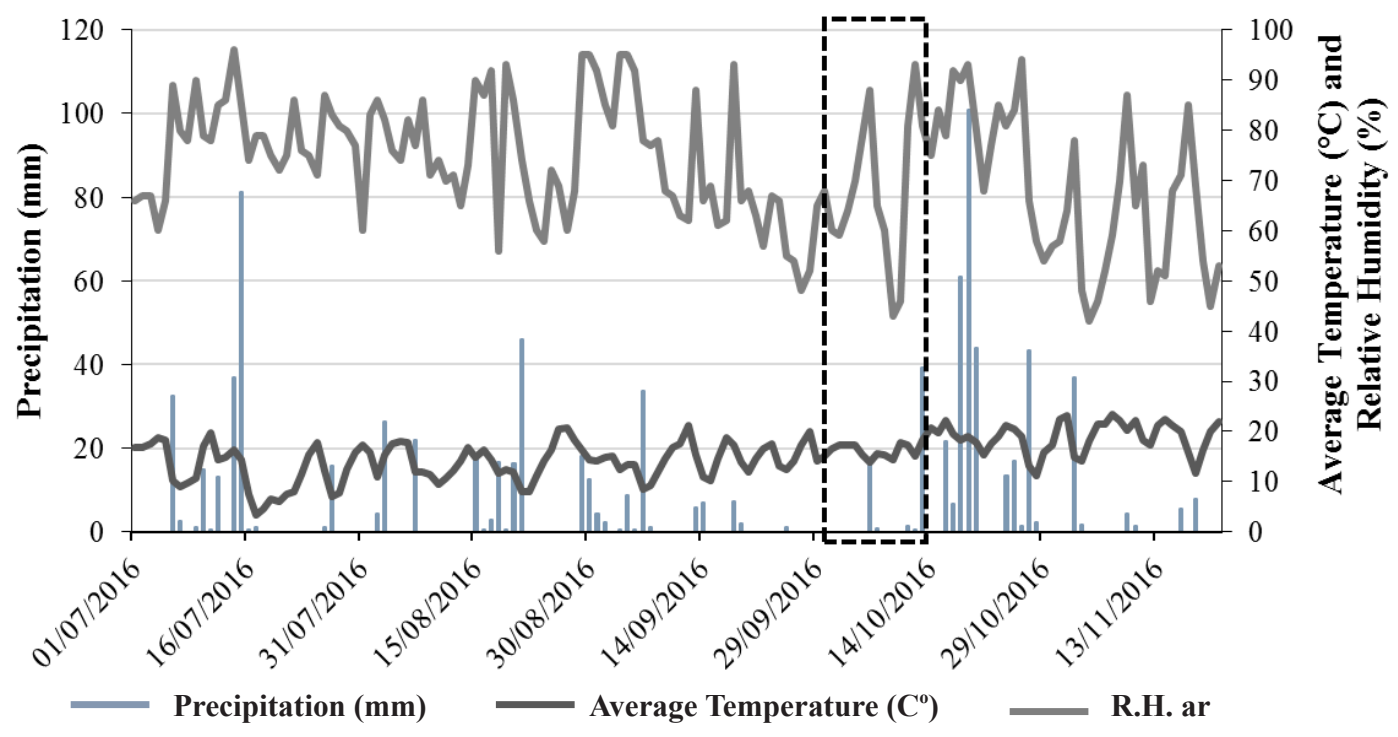

Figure 1. Daily weather data of pluvial precipitation $(\mathrm{mm})$, relative humidity $(\%)$ and average temperature $\left({ }^{\circ} \mathrm{C}\right)$ throughout the wheat crop cycle, conducted in 2016 in Passo Fundo, RS. 


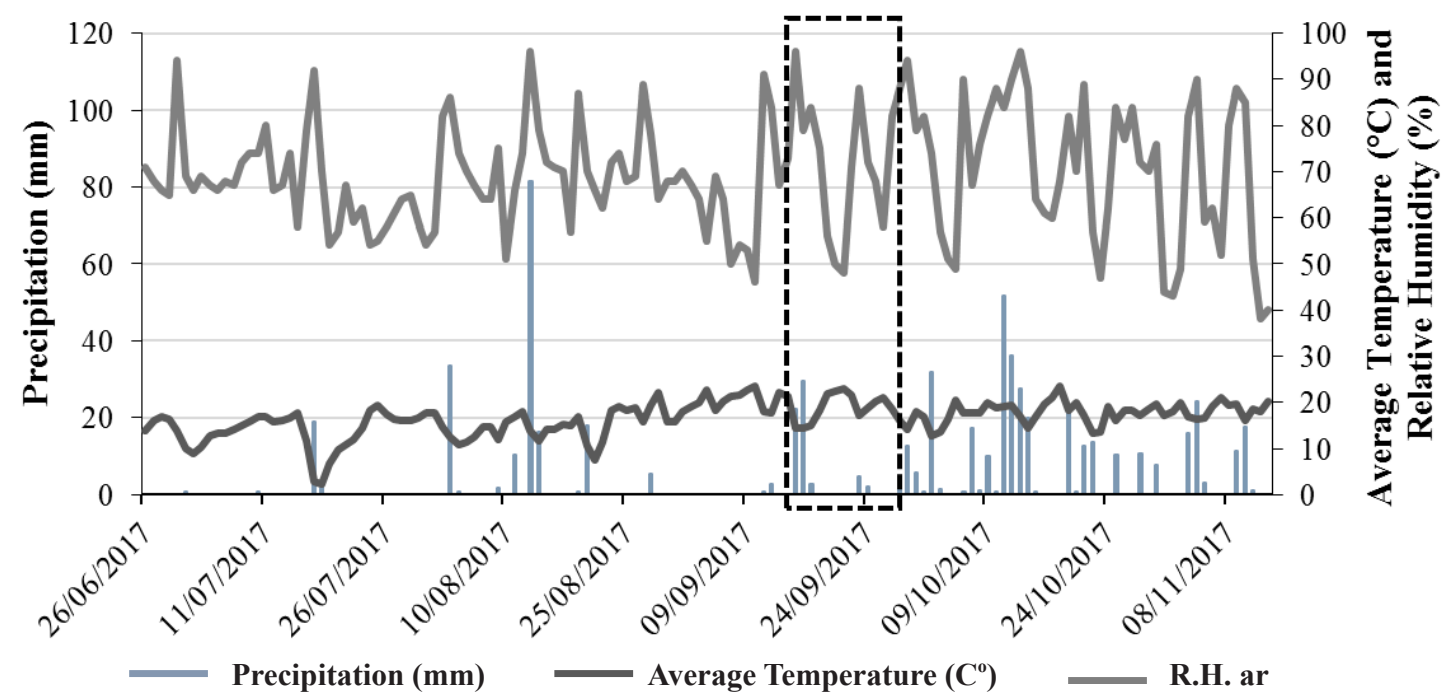

Figure 2. Daily weather data of pluvial precipitation $(\mathrm{mm})$, relative humidity $(\%)$ and average temperature $\left({ }^{\circ} \mathrm{C}\right)$ throughout the wheat crop cycle, conducted in 2017 in Passo Fundo, RS.

\section{Procedures}

For the first crop cycle (first year), sowing was done on 01/07/2016 and, for the second one (second year), sowing was done on 26/06/2017, according to the Agro Climatic Risk Zonation Calendar for Rio Grande do Sul, Municipality of Passo Fundo (18). Sowing density was 330 viable seeds $/ \mathrm{m}^{2}$, and the basis fertilizer was $300 \mathrm{~kg} / \mathrm{ha}$, commercial formula 10-26-23 $\left(\mathrm{N}-\mathrm{P}_{2} \mathrm{O}_{5}-\mathrm{K}_{2} \mathrm{O}\right)$. The plots measured $6.0 \mathrm{~m}^{2}, 5.0 \mathrm{~m}$ length $\mathrm{x} 1.2 \mathrm{~m}$ width, and had seven lines of sowing spaced $0.17 \mathrm{~m}$ from each other. The cultural treatments (control of weeds, plagues and leaf diseases) were performed according to the technical recommendation for wheat (11).

In both years, plots were irrigated during the whole flowering period (20 days) through an irrigation system with intermittent formation of water mist under the spikes. In addition, previously colonized wheat grains containing $7.0 \mathrm{~g} / \mathrm{m}^{2}$ perithecia (15) next to the irrigation hoses allocated between plots were distributed on the ground, beside each plot, in order to facilitate fungal dispersion by water splashes under the spikes at 50, and emergence of the cob (28).
Fungicide applications were performed with pressurized $\mathrm{CO}_{2}$ and knapsack sprayer fitted with a bar equipped with three nozzles with TTJ60 11002 double plan jet $30^{\circ}$ forward and $30^{\circ}$ backwards, operated at a pressure of $3.5 \mathrm{bar}(350 \mathrm{kPa})$, forming drops of average category (6) and syrup volume of $150 \mathrm{~L} / \mathrm{ha}$.

\section{Assessments}

Fusarium head blight intensity (\%) and control effectiveness (\%)

When wheat plants reached the stage of physiological maturity [stage 90 according to the scale of Zadoks et al. (28)], already showing early symptoms of the disease, the ears were collected from $1.0 \mathrm{~m}$ of the central row and frozen until evaluation. The incidence in ears (IE) was determined, including healthy and unhealthy (symptomatic) ears, where $\mathrm{IE}=[$ (Number of unhealthy ears/total number of spikes on the line $) *$ 100]. The incidence in spikelets was also found by counting the healthy and unhealthy spikelets, where $\mathrm{Ie}=[$ (Number of unhealthy spikelets/ number of spikelets on the ears) $* 100]$. The values were expressed as incidence (\%). Based on these variables, the disease intensity was

Table 1. Description of fungicide components in the treatments for the control of fusarium head blight in wheat cultivar Toruk, crop cycles 2016 and 2017. University of Passo Fundo, Passo Fundo, RS, 2018.

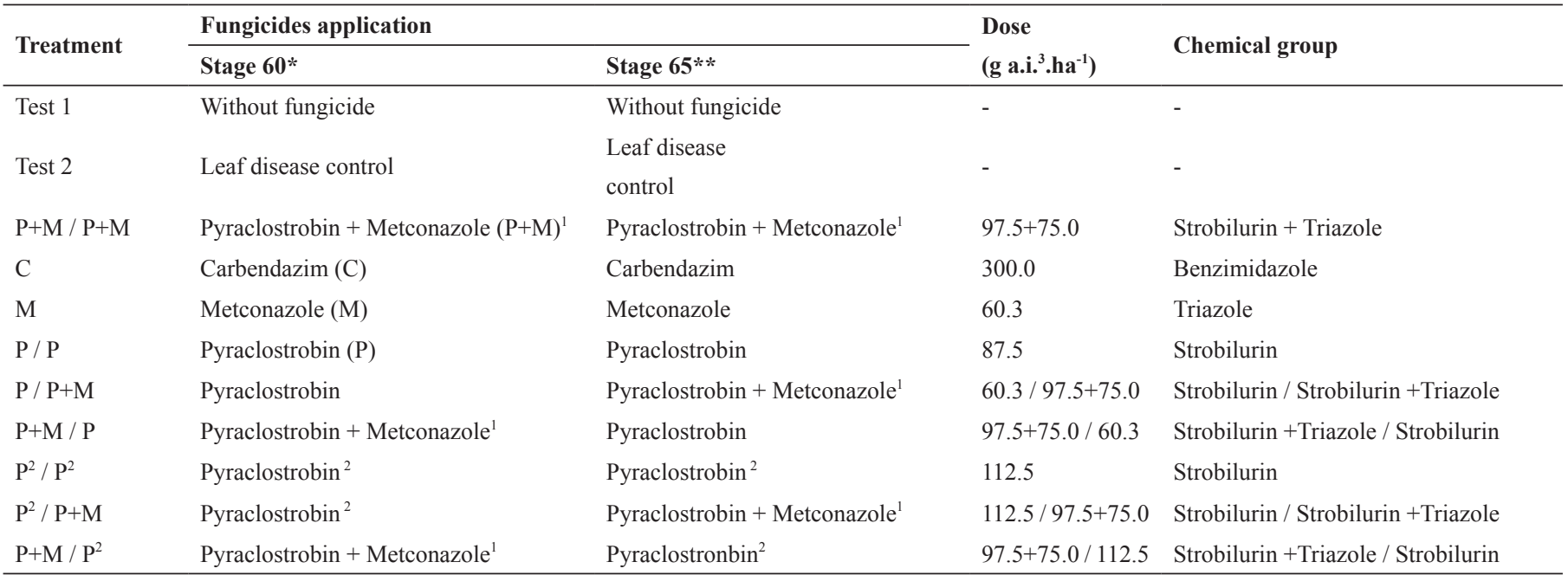

*Stage 60 , beginning of anthesis $(\approx 10 \%) .{ }^{* *}$ Stage 65 , flourishing until the top of the spike. ${ }^{1}$ Adjuvant mineral oil $0.5 \mathrm{~L} / \mathrm{ha}^{2}$ Dose of $112.5 \mathrm{~g}$ a.i./ha. ${ }^{3}$ Active ingredient. 
estimated by the formula $[\mathrm{IG}=((\mathrm{IE} x \mathrm{Ie}) / 100)]$, where $\mathrm{IE}=$ incidence in spikes; Ie = incidence in spikelets (30). Control effectiveness (\%) was calculated by the formula $[\mathrm{E} \%=((\mathrm{E}-\mathrm{F}) / \mathrm{E}) \times 100], \mathrm{E}=$ average intensity in control (treatment "1-Test, without fungicide)"; F = average intensity in each treatment.

\section{Grain yield}

When wheat plants reached the ideal humidity, mechanized harvesting of the entire plot was conducted, for a useful area of 6.0 $\mathrm{m}^{2}$. Grain weight and moisture content were determined. Grain yield was calculated as $\mathrm{kg} / \mathrm{ha}$, and moisture content was converted to $13 \%$.

\section{Deoxynivalenol contamination in grains}

After harvest in the first year, a 50g aliquot from each plot (200 $\mathrm{g}$ each treatment) was collected and analyzed in the Laboratory of Cereals, located in CEPA-Research Center on Feeding, University of Passo Fundo. Mycotoxin extraction was performed according to the Quick, Easy, Cheap, Effective, Rugged, Safe (QuEChERS) approach (2) and analyzed based on the technique of Liquid Chromatography with Sequential Mass Spectrometry (LC-MS/MS) in triplicate at the Laboratory of Cereals - CEPA/University of Passo Fundo.

In the second year, the sampling methodology was the same and the analyses were conducted at the Industrial Quality Laboratory of Biotrigo Genetics' Company, where mycotoxin quantifications were carried out after extraction according to the immunoenzymatic technique Enzyme-linked immunosorbent assay (ELISA) and analysis based on sequential mass spectrophotometry. Results were expressed as micrograms per kilogram $(\mu \mathrm{g} / \mathrm{kg})$.

\section{Data analysis}

The obtained data were subjected to analysis of variance (F-Test at $5 \%$ probability of error); if significant differences were detected among treatments, they were compared according to Scott-Knott test at $5 \%$ probability of error.

\section{RESULTS}

The tested fungicides had a significant effect on the assessed features (Tables 2 and 3). On average, fungicide application in the vegetative stage of wheat resulted in $20.5 \%$ fusarium head blight control; therefore, maintenance of healthy plants by controlling foliar diseases in pre-earing has an effect on the intensity of fusarium head blight in spikes. For disease intensity (IG), a higher dose of strobilurin alone $\left(\mathrm{P}^{2}+\mathrm{P}^{2}\right)$ resulted in increased disease intensity in both years, reducing control (Tables 2 and 3 ) when compared to the treatment $(\mathrm{P} / \mathrm{P})$ that received the standard dose of strobilurin.

The variables incidence in spikes (IE) and IG, in the first year, had the same behavior, not showing statistical differences among treatments. In general, the treatments provided protection to the spike as a whole, according to IE. Nonetheless, the fungicide carbendazim (treatment C) had the smallest incidence in spikelets (Ie): 9.6\% (Table 2). In the second year, there was no difference in IE among the applied fungicides. However, Ie was greater for the treatment that received two sequential applications of pyraclostrobin at a higher dose $\left(\mathrm{P}^{2} / \mathrm{P}^{2}\right)$ (Table 3$)$.

According to the study conducted by Machado (16), using metaanalysis for fungicide effectiveness on fusarium head blight control in Brazil, intensity of fusarium head blight $<7 \%$ is considered low and $>7 \%$, high. Therefore, in the first year (2016 crop cycle), the intensity was low due to unfavorable environmental conditions for the occurrence of the disease. In the following year, the intensity was high ( $\mathrm{IG}>7 \%)$.

Although there were no significant differences among treatments, carbendazim presented greater efficacy in controlling fusarium head blight in the two studied years (67\% and $75 \%$, respectively). For the first year, there was no consistency between the results of control efficiency and intensity of fusarium head blight considering the use of the strobilurin alone in the first or second application.

Considering DON values, higher doses of pyraclostrobin $\left(\mathrm{P}^{2} /\right.$ $\left.\mathrm{P}^{2}\right)$, compared to the standard dose $(\mathrm{P} / \mathrm{P})$ in the first year, resulted in increased mycotoxin accumulation in the grains, while in the second year, there was no direct relationship between the disease intensity in spikes and DON accumulation in the grains. However, the use of strobilurin alone in the first application contributed to the reduction in DON accumulation in the first year, although there was no increase in

Table 2. Intensity of fusarium head blight (IG), effectiveness of control (C), incidence in spikes (IE), incidence in spikelets (Ie), grain yield and concentration of deoxynivalenol (DON) in grains of wheat, cultivar TBIO Toruk, crop cycle 2016. University of Passo Fundo, Passo Fundo, RS, 2018

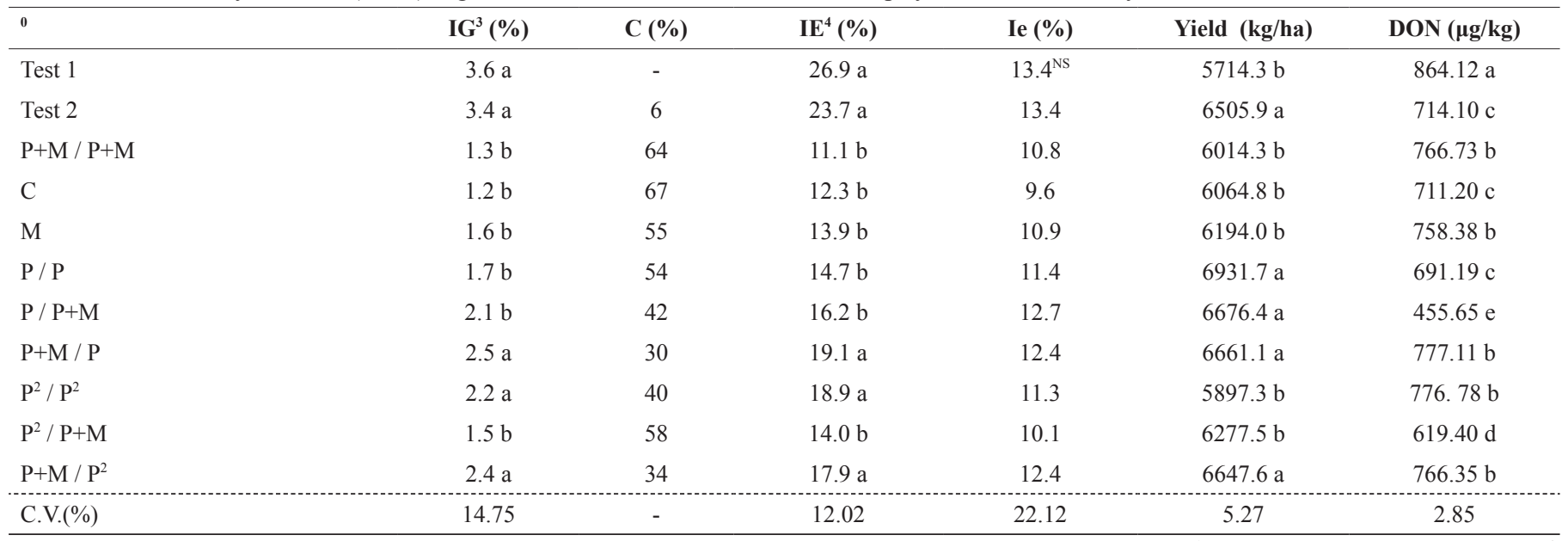

* Values followed by the same letter in the column do not differ significantly according to Scott-Knott test at $5 \%$ probability. ${ }^{1}$ Treatment discriminated in Table $1 .{ }^{2}$ Dose of $112.5 \mathrm{~g}$ a.i./ha. ${ }^{3}$ Values subjected to statistical analysis $[\log (\mathrm{x})]$ and $(\mathrm{X}+\mathrm{C}) .{ }^{4}$ Values subjected to statistical analysis $\log (\mathrm{x})$. NS- Not significant differences among the treatments according to F-test at $5 \%$ probability. 
Table 3. Fusarium head blight intensity (IG), effectiveness of control (C), incidence in spikes (IE), incidence in spikelets (Ie), grain yield and concentration of deoxynivalenol (DON) in grains of wheat, cultivar TBIO Toruk, crop cycle 2017. University of Passo Fundo, Passo Fundo, RS, 2018

\begin{tabular}{|c|c|c|c|c|c|c|}
\hline Treatment $^{1}$ & $I^{3}(\%)$ & $\mathrm{C}(\%)$ & IE (\%) & Ie $(\%)$ & Yield (kg/ha) & DON $(\mu \mathrm{g} / \mathrm{kg})$ \\
\hline Test 1 & $10.8 \mathrm{a}^{*}$ & - & $73.3 \mathrm{a}^{*}$ & $14.6 \mathrm{a}^{*}$ & $3067.0 c^{*}$ & $1650.0 \mathrm{a}^{*}$ \\
\hline Test 2 & $6.9 \mathrm{a}$ & 35 & $64.3 \mathrm{a}$ & $10.7 \mathrm{~b}$ & $3466.4 \mathrm{~b}$ & $1350.0 \mathrm{~b}$ \\
\hline $\mathrm{C}$ & $2.7 \mathrm{~b}$ & 75 & $30.4 \mathrm{~b}$ & $8.9 \mathrm{~b}$ & $3939.3 \mathrm{a}$ & $850.0 \mathrm{c}$ \\
\hline M & $4.4 \mathrm{~b}$ & 59 & $44.8 \mathrm{~b}$ & $9.9 \mathrm{~b}$ & $4108.5 \mathrm{a}$ & $650.0 \mathrm{~d}$ \\
\hline $\mathrm{P}+\mathrm{M} / \mathrm{P}$ & $4.0 \mathrm{~b}$ & 62 & $37.4 \mathrm{~b}$ & $10.4 \mathrm{~b}$ & $4312.8 \mathrm{a}$ & $500.0 \mathrm{~d}$ \\
\hline $\mathrm{P}^{2} / \mathrm{P}^{2}$ & $8.0 \mathrm{a}$ & 26 & $49.6 \mathrm{~b}$ & $15.9 \mathrm{a}$ & $4226.3 \mathrm{a}$ & $650.0 \mathrm{~d}$ \\
\hline $\mathrm{P}^{2} / \mathrm{P}+\mathrm{M}$ & $4.7 \mathrm{~b}$ & 57 & $41.9 \mathrm{~b}$ & $10.4 \mathrm{~b}$ & $4177.2 \mathrm{a}$ & $850.0 \mathrm{c}$ \\
\hline $\mathrm{P}+\mathrm{M} / \mathrm{P}^{2}$ & $4.9 \mathrm{~b}$ & 54 & $47.0 \mathrm{~b}$ & $10.3 \mathrm{~b}$ & $4287.5 \mathrm{a}$ & $800.0 \mathrm{c}$ \\
\hline C.V. $(\%)$ & 10.40 & - & 24.63 & 25.60 & 4.69 & 12.17 \\
\hline
\end{tabular}

the income and no reduction in the disease intensity (Table 2). In the second year, the higher dose increased the disease intensity in the cob, but the same did not occur for DON accumulation in the grains (Table 3).

\section{DISCUSSION}

In the first year, the anthesis of wheat lasted 14 days, from 30/09 to $13 / 10 / 2016$ and, during this period, the average temperature was $16.2^{\circ} \mathrm{C}$ (minimum $6.5^{\circ} \mathrm{C}$ and maximum $26.1^{\circ} \mathrm{C}$ ); accumulated rainfall was $58.5 \mathrm{~mm}$, distributed during 5 days. In the second year, anthesis lasted 15 days, from $14 / 09$ to $28 / 09 / 2017$, when the average temperature was $18.9^{\circ} \mathrm{C}$ (minimum $11.5^{\circ} \mathrm{C}$ and maximum $31.0^{\circ} \mathrm{C}$ ); rainfall was $63.8 \mathrm{~mm}$, distributed during 6 days. In general, these weather conditions were below the ideal for pathogen infection. According to the study conducted by Andersen (3), the optimal temperature for the development of fusarium head blight is $25^{\circ} \mathrm{C}$, regardless of wetness duration. Thus, the studied years were distinct and unrelated since environmental conditions for the occurrence of the disease and for the development of wheat caused marked differences in IG. Considering DON accumulation and grain yield between crop years for these variables, in the second year there was an increase for all treatments of $3.3 \%$ and $94.23 \mu \mathrm{g} / \mathrm{kg}$ and a reduction of $2330 \mathrm{~kg} / \mathrm{ha}$, respectively. In addition, the mean IG value for treatment Test 1 (without fungicide) was $3.6 \%$ in the first year (Table 2) and $10.8 \%$ in the second year (Table $3)$, i.e., the latter was three times higher than that in the first year.

Chemical control influenced the incidence and the severity of the disease in spikes and the accumulation of the mycotoxin deoxynivalenol in grains. Accordingly, the growth of pathogenic agents and their pathogenicity expression in the host are indirectly quantified as disease intensity; however, the factors that promote the growth of the pathogen can also promote the production of DON (27). The active principle pyraclostrobin, depending on the used dose and application time, has negative effects by reducing the control and changing the toxin production. The results found for DON in the first year were below the maximum tolerable limit $(2017: 1250 \mu \mathrm{g} / \mathrm{kg})$ for the trading of whole wheat and wheat bran according to the Brazilian legislation (5). In the second year, the values were higher than those tolerable by the national legislation. A positive correlation has been reported between the amount of DON produced by $F$. graminearum and fungus biomass, as well as between the intensity of fusarium head blight in field trials and the concentration of the toxin in grains (21). Nevertheless, this correlation could not be verified in the present study because the treatments with lower IG were not necessarily those that presented the lowest DON accumulation.

There are reports in the literature showing that application of fungicides of the strobilurin group, alone or in combination, has resulted in low fusarium head blight control and increased grain contamination by DON $(1,7)$. Considering the average of the two years, the rise in the recommended dose of pyraclostrobin to $25 \mathrm{~g}$ a.i./ ha $\left(\mathrm{P}^{2} / \mathrm{P}^{2}\right)$ in two separate applications caused a reduction of $20 \%$ in the control of fusarium head blight and an increase of $85.6 \mu \mathrm{g} / \mathrm{kg}$ in DON accumulation in the first year. Nonetheless, in the second year, the opposite effect was found for DON content; there was a reduction of 200 $\mu \mathrm{g} / \mathrm{kg}$ in the toxin. In addition, based on the average of the two years, the increase in the first-dose application $\left(\mathrm{P}^{2} / \mathrm{P}+\mathrm{M}\right)$ provided greater control (9\%). However, the average increase in the dose of strobilurin on the second application $\left(\mathrm{P}+\mathrm{M} / \mathrm{P}^{2}\right)$ did not have the same behavior, reducing control to $4 \%$. Among the chemical group of strobilurins, azoxystrobin has already had its ineffectiveness documented in vitro and in wheat grains for the control of Fusarium species, while its sub-doses can stimulate the production of mycotoxins (17). As in the second year the intensity of the disease was higher than in the first year, the applied fungicides may have caused greater stress to the fungus, which produced a higher quantity of DON toxins. A large number of studies have been conducted to relate the intensity of fusarium head blight with DON production in winter cereals but no concrete results were found $(8,13)$.

Besides the negative effects caused by azoxystrobin, pyraclostrobin has generated effects on the fungus at sub or high-dosage and depending on the moment of its application. Strobilurins are able to induce oxidative stress in response to Fusarium species (7); thus, according to Reverberi et al. (25), they play a major role in the control of toxin synthesis. Inconsistent and conflicting effects on fusarium head blight control have been reported for fungicides considering mycotoxin accumulation in contaminated grains (23). Triazoles are more efficient in controlling fusarium head blight and reducing DON accumulation; among strobilurins, as they are associated with high levels of DON in 
grains (27), prothioconazole and metconazole were most effective in controlling fusarium head blight and DON contamination (22). The higher dose of metconazole increased the control, which ranged from $77 \%$ to $98 \%$, when most effective. Control provided by strobilurin was $30 \%$ to $55 \%$, showing no statistical difference between doses of azoxystrobin and management; increasing doses of strobilurin did not significantly affect the concentrations of DON (23). Carbendazim had an intermediate behavior among other fungicides tested in this study for DON accumulation; however, despite providing greater disease control, it has the ability to increase the levels of DON in wheat grains (19). Fungicides may act as additional stress to stimulate the synthesis of mycotoxins as a defense response (17). Siranidou \& Buchenauer (26) applied the fungicides tebuconazole and metconazole on wheat ears inoculated with [F. culmorum (W. G. Smith) Sacc.] and reported a reduction in the disease by $60-70 \%$ and in DON levels by $50-70 \%$; however, azoxystrobin reduced the disease incidence despite increasing DON concentrations.

In the second year, there were no differences between the tested fungicides and grain yield; in this case, most fungicides reduced fusarium head blight index and DON accumulation, while the performance was better, compared to control without application. These same results were found by Amarasinghe et al. (1), who stated that fungicides may delay the development of fusarium head blight in grains in such a way that early infections lead to more infected grains, which tend to be light and blown out of the harvester, while heavier grains due to later infections can lead to increased DON levels since they are retained in the harvesting process.

Foliar wheat diseases can increase the susceptibility of the spike to fusarium head blight (20). However, these diseases seem not to be related to the severity of fusarium head blight in spikes. Leaf disease control is known to be independent of fusarium head blight control (24). The results found in the current study, in general, show that foliar disease control does not statistically reduce fusarium head blight symptoms, compared to absolute control. Nevertheless, foliar disease control in absolute terms provided $20.5 \%$ control of fusarium head blight and significantly increased grain yield. This rise may be related to the resistance of leaf diseases in cultivars, which influences the success of fusarium head blight control (20).

In conclusion, chemical control of fusarium head blight in wheat influences the disease intensity in spikes and deoxynivalenol contamination in the grains. The fungicide carbendazim, of the benzimidazole chemical group, used alone, is effective in controlling fusarium head blight in wheat, distinguishing from the groups triazole (metconazole) and strobilurin (pyraclostrobin) under the same conditions. In addition, comparing the chemical groups triazole and strobilurin alone, triazole is more efficient in reducing the disease intensity. The use of pyraclostrobin at different doses and implementation levels changed the intensity of fusarium head blight, the accumulation of DON and the grain yield, depending on the environmental conditions and the intensity of inherent diseases of each crop year.

\section{ACKNOWLEDGMENTS}

The authors are thankful to the Graduate Program in Agronomy (PPGAgro) of University of Passo Fundo and CAPES.

\section{REFERENCES}

1. Amarasinghe, C.C.; Tamburic-ilincic, L.; Gilbert, J.; Brûlé-Babel, A.L.; Fernando, W.G.D. Evaluation of different fungicides for control of Fusarium head blight in wheat inoculated with $3 \mathrm{ADON}$ and $14 \mathrm{ADON}$ chemotypes of Fusarim graminearum in Canada. Canadian Journal of Plant Pathology, Canadá, v.35, n.2, p.200-208, 2013.

2. Anastassiades, M.; Lehotay, S.J. Fast and Easy Multiresidue Method Employing Acetonitrile Extraction/Partitioning and "Dispersive Solid-Phase Extraction" for the Determination of Pesticide Residues in Produce. Journal of AOAC International, s.1., v.86, n.2, p.412-431, 2003.

3. Andersen, A.L. The development of Gibberella zeae head blight of wheat. Phytopathology, St. Paul, v.38, p.599-611, 1948.

4. Andersen, K.F.; Morris, L.; Derksen, R.C.; Madden, L.V.; Paul, P.A. Rainfeastness of prothioconazole + tebuconazole for fusarium head blight and deoxinivalenol management in soft red winter wheat. Plant Disease, St. Paul, v.98, n.10, p.1398-1406, 2014.

5. Anvisa. Resolução RDC no 7, de 18 de fevereiro de 2011. Regulamento técnico sobre limites máximos tolerados (LMT) para micotoxinas em alimentos. Diário Oficial da União, Brasília, DF, 2011.

6. ASABE. Standard S572.1: Spray nozzle classification by droplet spectra. St. Joseph: ASABE, 2009.

7. Audenaert, K.; Callewaert, E.; Höfte, M.; Saeger, S.D.; Haesaert, G. Hydrogen peroxidase induced by the fungicide prothioconazole triggers deoxynivalenol (DON) production by Fusarium graminearum. BMC Microbiology, Ghent, v.10, n.112, p.2-14, 2010.

8. Bai, G.H.; Plattner, R.; Desjardins, A.; Kolb, F. Resistance of fusarium head blight and deoxynivalenol accumulation in wheat. Plant Breeding, Berlin, v.120, p.1-6, 2001.

9. Baturo-Ciesniewska, A.; Lukanowski, A.; Kolenda, M. Effect of fungicide application on Wheat Head Blight, occurrence of Fusarium spp. and mycotoxin production. Plant Breeding and Seed Science, Bydgoszcz, v.63, p.30-38, 2011.

10. Cowger, C.; Arellano, C. Fusarium graminearum infection and deoxinivalenol concentrations during development of wheat spikes. Phytopathology, St. Paul, v.103, n.5, p.460-471, 2013.

11. Cunha, G.R.; Caierão, E.; Rosa, A.C. Informações técnicas para trigo e triticale - safra 2016 - $9^{\mathrm{a}}$ Reunião da Comissão Brasileira de Pesquisa de Trigo e Triticale. Passo Fundo: Biotrigo Genética, 2016. Boletim Técnico.

12. Edwards, S.G.; Pirgozliev, S.R.; Hare, M.C.; Jenkinson, P. Quantification of trichothecene-producing Fusarium species in harvested grain by competitive PCR to determine efficacies of fungicides against Fusarium head blight of winter wheat. Applied and Environmental Microbiology, s.l., v.67, n.4, p.1575-1580, 2001.

13. Ji, F.; Wu, J.; Zhao, H.; Xu, J.; Shi, J. Relationship of deoxynivalenol content in grain, chaff, and straw with Fusarium head blight severity in wheat varieties with various levels of resistance. Toxins, Basileia, v.7, n.3, p. $728-742,2015$.

14. Lima, M.I.P.M. Avaliação de cultivares de trigo à giberela. 2012. $112 \mathrm{f}$. Tese (Doutorado em Agronomia) - Faculdade de Agronomia e Medicina Veterinária, Universidade de Passo Fundo, Passo Fundo.

15. Lima, M.I.P.M. Protocolo usado na Embapa Trigo para produção de peritécios de Gibberella zeae em grãos de trigo. Passo Fundo: Embrapa Trigo, 2007. (Comunicado Técnico, 218).

16. Machado, F.J. Giberela do trigo: resistência a fungicidas e metanálise da eficácia do controle químico. 2016. 78f. Dissertação (Mestrado em Fitopatologia) - Universidade Federal de Viçosa, Viçosa.

17. Magan, N.; Hope, R.; Colleate, A.; Baxter, E.S. Relationship between growth and mycotoxin production by Fusarium species, biocides and environment. European Journal of Plant Pathology, s.1., v.108, n.7, p.685-690, 2002.

18. MAPA. Portaria $n^{\circ} 262,22$ de dezembro de 2015. Zoneamento Agrícola de Risco Climático para a cultura do trigo no Estado do Rio Grande do Sul. Diário Oficial da União, Brasília, DF, 2015.

19. Mesterházy, A.; Bartók, T.; Lamper, C. Influence of cultivar resistance, epidemic severity, and Fusarium species on the efficacy of fungicide control of Fusarium head blight in wheat and deoxynivalenol (DON) contamination of grain. Plant Disease, St. Paul, v.87, n.9, p.1107-1115, 2003.

20. Mesterházy, A.; Tóth, B.; Verga, M.; Bartók, T.; Szabó-Hevér, A.; Farády, L.; Lehoczki-Hrsjak, S. Role of fungicides, application of nozzle types, and the resistance level of wheat varieties in the control of Fusarium Head Blight and deoxynivalenol. Toxins, Basileia, v.3, n.11, p.1453-1483, 2011.

21.Nicholson, P.; Turner, J.A.; Jenkinson, P.; Jennings, P.; Stonehouse, J.; 
Nuttall, M.; Dring, D.; Weston, G.; Thomsett, M. Maximizing control with fungicides of Fusarium ear blight (FEB) in order to reduce toxin contamination of wheat. Home-Grown Cereals Authority, 2003. Project Report, 297.

22. Paul, P.A.; Lipps, P.E.; Hershman, D.E.; Mcmullen, M.P.; Draper, M.A.; Madden, L.V. Efficacy of triazole-based fungicides for fusarium head blight and deoxynivalenol control in wheat: a multivariate meta-analysis. Phytopathology, St. Paul, v.98, n.9, p.999-1011, 2008.

23. Pirgozliev, S.R.; Edwards, S.G.; Hare, M.C.; Jenkinson, P. Effect of dose rate of azoxystrobin and metconazole on the development of Fusarium head blight and the accumulation of deoxynivalenol (DON) in wheat grain. European Journal of Plant Pathology, s.1., v.108, n.5, p.469-478, 2002.

24. Reis, E.M.; Boareto, C.; Danelli, A.L.D.; Zoldan, S.M. Anthesis, the infectious process and disease progress curves for fusarium head blight in wheat. Summa Phytopathologica, Botucatu, v.42, n.2, p.134-139, 2016.

25. Reverberi, M.; Ricelli, A.; Zjalic, S.; Fabbri, A.A.; Fanelli, C. Natural func- tions of mycotoxins and control of their biosynthesis in fungi. Appllied Microbiology and Biotechnology, s.1., v.87, n.3, p.899-911, 2010.

26. Siranidou, E.; Buchenauer, H. Chemical control of Fusarium head blight on wheat. Journal of Plant Diseases and Protection, Dordrecht, v.108, p.231-243, 2001.

27. Wegulo, S.N. Factors influencing deoxynivalenol accumulation in small grain cereals. Toxins, Basileia, v.4, n.11, p.1157-1180, 2012.

28. Zadoks, J.C.; Chang, T.T.; Konzak, C.F. A decimal code for the growth stages of cereals. Weed Research, s.1., v.14, n.6, p.415-421, 1974.

29. Zhang, Y.; Yu, J.; Zhang, Y.; Zhang, X.; Cheng, C.; Wang, J.; Hollomon, D. W.; Fan, P.; Zhou, M. Effect of carbendazim resistance on trichothecene production and aggressiveness of Fusarium graminearum. Molecular Plant-Microbe Interactions, Bethesda, v.22, n.9, p.1143-1150, 2009.

30. Zoldan, S.M. Regiões de risco, caracterização da antese em cereais de inverno e sistema de alerta para a giberela, em trigo. 2008. 152f. Tese (Doutorado em Agronomia) - Faculdade de Agronomia e Medicina Veterinária, Universidade de Passo Fundo, Passo Fundo. 